Open Access

\title{
How entrepreneurs learn in their region: entrepreneurial strategies, financialisation and narrative learning in the Vienna biotechnology cluster
}

Maximilian Fochler(i)

Correspondence:

maximilian.fochler@univie.ac.at

Universitat Wien, Wien, Austria

\begin{abstract}
How entrepreneurs plan their business and build their companies plays a central role in how academia-industry-government relations are shaped in a particular region. But how do specific regional styles of building companies and understanding these relations develop? This paper conceptualises the entrepreneurs in a cluster as a community of practice and shows that narrative learning in this community of practice plays a crucial role in how they develop their strategies. Entrepreneurs consider and learn from stories about past successes and failures in the cluster. In particular, they engage with these stories to make sense of what they strive for in building a successful company. Dealing with the complex dynamics of financialisation plays a crucial role in this learning process. This paper is empirically based on biographical interviews with entrepreneurs and serial entrepreneurs in the Vienna biotechnology cluster.
\end{abstract}

Keywords: Academia/industry relations, Cluster, Venture capital, Entrepreneur, Biotechnology, Learning, Financialisation

\section{摘 要}

创业者如何规划他们的生意，建立自己的公司，这对于如何在特定的区域形成学 术界-产业-政府间的关系起着核心的作用。但是正在打造的公司的具体区域类 型怎样形成?如何理解发展这些关系?本文把在产业集群中的创业者概念化为实 践共同体,并展示在这一实践共同体中叙事性学习怎样在他们制定战略时起至关 重要的作用。创业者们思考和学习在产业集群中过去的成败故事。特别是，他 们利用这些故事理解为建立一个成功的公司而奋斗的意义。在这一学习过程中， 处理金融化复杂动力学起了关键的作用。本文所进行的实证研究基于对维也纳 生物技术产业集群中的创业者的系列访谈和对一批创业者的传记性采访。

关键词: 学术/产业关系、产业集群、风险投资、创业者、生物技术、学习、 金融化 


\section{Résumé}

La manière dont les entrepreneurs planifient leurs affaires et bâtissent leurs entreprises détermine le type de relations entre université, industrie et gouvernement dans une région donnée. Mais comment se développent les styles régionaux spécifiques de construction d'entreprise et de compréhension de ces relations ? Cet article conceptualise les entrepreneurs comme une communauté de pratiques et montre que l'apprentissage narratif joue un rôle crucial dans le développement de leurs stratégies. Les entrepreneurs accordent une importance à l'histoire de ces entreprises et tirent une leçon de leur réussite ou de leur échec. En particulier, ils s'intéressent à leurs histoires pour mieux comprendre ce qu'ils vivent dans leurs propres stratégies pour bâtir des entreprises prospères. La gestion de la dynamique complexe de la financiarisation joue un rôle crucial dans ce processus d'apprentissage. Cet article repose empiriquement sur des entretiens biographiques avec des entrepreneurs et des 'serial' entrepreneurs du pôle de biotechnologie de Vienne.

Mots clés: relations université/industrie, pôle d'entreprises, capital risque, entrepreneur, biotechnologie, apprentissage, financiarisation

\section{Resumo}

Como empreendedores planejam seus negócios e constroem suas companhias desempenham papel crucial em como as relações entre academia-indústria-governo são moldados em uma determinada região. Mas como os estilos regionais específicos das empresas de construção e a compreensão dessas relações se desenvolvem? Este artigo conceitua os empreendedores em um grupo como uma comunidade de prática e mostra que a aprendizagem narrativa nesta comunidade de prática desempenha um papel crucial na forma como desenvolvem suas estratégias. Os empreendedores consideram e aprendem com histórias sobre sucessos e fracassos no grupo. Em particular, eles se envolvem com essas histórias para entender o que eles buscam na construção de uma empresa de sucesso. Lidar com a complexa dinâmica da financeirização desempenha um papel crucial neste processo de aprendizagem. Este trabalho é empiricamente baseado em entrevistas biográficas com empresários e empreendedores em série no grupo de biotecnologia de Viena.

Palavras chaves: Academia/relações da indústria, cluster, capital de risco, empreendedor, biotecnologia, aprendizagem, financeira

\section{Аннотация}

Подход предпринимателей к планированию бизнеса и созданию собственных компаний играет ключевую роль в том, как сформированы отношения университетпромышленность-правительство в конкретном регионе. Но как развиваются специфические региональные схемы построения компаний и понимание этих отношений? В настоящей статье представлена концепция объединения предпринимателей в кластере, где участники обмениваются опытом на практических примерах, что оказывает значительную роль на развитие бизнесстратегий. Предприниматели собирают и изучают истории успеха и неудач других участников кластера. Благодаря этим историям они получают представление о том, как создать успешную компанию. Использование комплексной динамики финансизации играет значительную роль в этом образовательном процессе. Данная статья основана на биографических интервью предпринимателей, в том числе серийных, биотехнологического кластера Вены.

(Continued on next page) 
(Continued from previous page)

ключевые слова: Отношения университет/промышленность, кластер, венчурный капитал, предприниматель, биотехнология, обучение, финансизация

\begin{abstract}
Resumen
La manera en que los empresarios planean sus negocios y construyen sus compañías, determina el tipo de relaciones entre academia industria y gobierno. ¿Pero cómo se forman los estilos regionales de planificación y emprendimiento específicamente? Este artículo conceptualiza a los empresarios como una comunidad de práctica y muestra que las narrativas pedagógicas en esta comunidad juegan un papel crucial en la forma en que establecen sus negocios porque los empresarios aprenden tanto del mito como de la realidad de éxitos y fracaso de negocios similares; estas narrativas forman las imágenes mentales que los empresarios usan para establecer sus propios objetivos y estrategias. En particular, estas historias resuelven la compleja dinámica de la capitalización financiera. Nuestros resultados reportados aquí se basan en entrevistas biográficas con empresarios y emprendedores seriales en el grupo de biotecnología de Viena, Austria.
\end{abstract}

Palabras Clave: Relaciones de academia e industria, sector económico, capital de riesgo, empresario, biotecnología, aprendizaje, financialización

\title{
Multilingual abstract
}

Please see Additional file 1 for translation of the abstract into Arabic.

\section{Introduction}

Regional innovation clusters are a crucial locus in the dynamic of academia, industry and government relations (Birch 2017a; Cooke 2001; Etzkowitz 2018). But who are the actors that shape the specific regional dynamic of how these domains are related? The importance of regional policy making and support structures has been pointed to (Huggins et al. 2008; Molina-Morales and Martínez-Cháfer 2014), as has been the role of entrepreneurial academics who patent and commercialise their university research (Feldman et al. 2005; Haeussler and Colyvas 2011). This paper focuses on a third group of crucial actors and innovation organisers: entrepreneurs and serial entrepreneurs which found high-tech companies in a specific region and sector (Feldman et al. 2005).

Company founders are institution builders and institutional entrepreneurs (Battilana et al. 2009) that choose how to draw on academic knowledge, which governmental and private funding arrangements to use to build their business, and how to relate the work in their company to other local and trans-local actors. To a significant degree, the specific ways in which academia, industry and government are related in a specific region are the result of this entrepreneurial work of innovation organisers (Etzkowitz and Ranga 2015). But which resources do entrepreneurs draw on in making these decisions? Which role does the regional context play in shaping them? And how do entrepreneurs consider and learn from previous experiences?

This paper conceptualises the entrepreneurs in a regional setting as a community of practice (Bathelt et al. 2004; Wenger 1998) and studies how learning takes place in this community of practice. Building on biographical interviews with entrepreneurs and 
serial entrepreneurs from the Vienna biotechnology cluster, it shows that narratives of past success and failures in the cluster play a crucial role for how entrepreneurs approach the way they build their companies.

Financialisation (Birch 2017a, 2017b; French et al. 2011; Lazonick and Tulum 2011) plays a key role in life science entrepreneurs' struggles and considerations. In relation to other high-tech sectors, the life sciences are characterised by very high risk and long development times. How to find forms of financing that fit these conditions and that still leave them agency to realise what they aim to achieve with their company is a central concern for entrepreneurs.

The paper proceeds by reviewing three lines of literature: the role of knowledge and learning in regional clusters, entrepreneurs as institution builders and the interrelation of financialisation and the biotech business model. After a description of material and methods, the empirical part of the paper analyses how entrepreneurs in the Vienna biotechnology cluster draw on stories of past success and failure in the cluster to make sense of and legitimate their own decisions in building their companies. The discussion summarises the contribution of the paper and a set of policy recommendations points to the relevance of its findings for regional innovation policy.

\section{Knowledge and learning in regional clusters}

The development of regional clusters of academic institutions and high-tech companies has been one of the strongest motives of innovation policy of the last decades. Also in the academic debate, whether local clustering provides advantages for innovation processes, and if so, why, has been debated. Both Birch (2017a) and Lagendijk (2006) distinguish between three phases in the literature on the geography of regional innovation, each answering the question why regionality makes a difference differently. In a first phase, which Birch labels as "functional" authors sought the advantage of co-location in material interdependencies between small firms along one production chain. In this line of thought, regional advantage arises from intense cooperation between firms along supply chains. In a second phase, social and institutional relations in a regional cluster moved centre stage. Concepts such as regional innovation systems (Cooke 2001) or innovative milieus (Crevoisier 2004) stressed the importance of systemic relations between different institutions in business, government and academia. Specific regional characteristics were seen as to be explained out of the specificities of these relations and of corresponding emergent social processes such as the building of trust relations. In a third phase, knowledge and cognitive processes were seen as central. In this line of literature, innovation is seen as crucially depending on companies' ability to integrate and use new knowledge (Bathelt et al. 2004; Håkanson 2005; Healy and Morgan 2012; Malmberg and Power 2005; Moodysson 2008). The role of codified and tacit knowledge, as well as how knowledge is differently transferred through local "buzz" or "global pipelines" (Bathelt et al. 2004), has been debated.

For most approaches in the "cognitive" line of literature, learning focuses on knowledge directly relevant to the commercial activities of the companies themselves. Reflexive knowledge, such as how to best build a company under the given regional 
conditions, is hardly considered. This question was more central in the "learning regions" debate (Hassink and Klaerding 2012; Rutten and Boekema 2012). Here, the reflexive capacity of different institutional actors to learn from each other is seen as a central characteristic of a successful regional innovation environment.

\section{Entrepreneurs as institution builders}

Entrepreneurs founding companies are institution builders and institutional entrepreneurs (Battilana et al. 2009) in a double sense (Feldman et al. 2005). First, their actions shape the companies they build, their business models, their social structure and their relations to academia, government and other actors such as funders. But second, in doing so, they also contribute to building the specific form of the cluster they are part of.

Understanding and analysing this interrelation is challenging. Autio et al. (2014) diagnose a divide in the literature, between approaches which mainly focus on individual entrepreneurs, but hardly consider their relation to the local context, and other literature such as the one on regional innovation systems which analyses regions as aggregated systems but struggles to consider individual agency (Trippl et al. 2015).

But how to conceptualise the way entrepreneurs relate to their context in a cluster? This question can be approached in multiple ways, through social network analysis (Porter et al. 2005) as well as by analysing the co-production of regional policy and entrepreneurial action (Molina-Morales and Martínez-Cháfer 2014). This paper will take a narrative approach.

Some authors in the cognitivist approach to regional innovation have conceptualised entrepreneurs in a cluster as a community of practice (Bathelt et al. 2004; Wenger 1998). Such a community is characterised by "joint enterprise, mutual engagement and a shared repertoire of actions, styles, artefacts, concepts, discourses, stories and histories" (Wenger 1998). Resonating with literature that stresses the importance of sense-making and narrative in the study of organizations (Czarniawska-Joerges 1998), this approach stresses the importance of discourses and stories circulating in a cluster for learning.

This paper will assume this perspective and conceptualise a specific cluster following Massey's definition of space as a "simultaneity of stories so far" (Massey 2005). Its hypothesis is that the circulation of stories and the way individual entrepreneurs make sense of them and apply them to their own situation is a major way in which individual entrepreneurial actions are linked to the longer-term dynamics of a specific cluster.

\section{Financialisation and the biotech business model}

The provision of capital is crucial to the regional development of high-tech industries. Particularly the venture capital industry has been shown to play a crucial role in the formation of clusters (Avnimelech and Teubal 2006). In theoretical terms, authors have described this influence as part of a general process of financialisation, that is the growing importance of processes of financing in relation to other processes in the economy, such as production (Birch 2017b; French et al. 2011). Financialisation implies that investors see a high-tech startup company as a financial asset to be bought and sold, rather than as an investment to profit from the sale of future products 
(Lazonick and Tulum 2011). As critical literature has pointed out, this may lead to an orientation towards short-term financial profit rather than a commitment to the long-term health of companies (French et al. 2011).

The biotech industry may be seen as both a paradigmatic and extreme example of financialisation (Birch 2017b; Lazonick and Tulum 2011). It is characterised by a high need of capital investments, extremely long development times of one or two decades from startup to market, and by a very high risk of fatal failure along the development pathway. Critical authors have shown that an overwhelming majority of biotech companies never actually bring any product to the market and that the overall profitability of the entire industry is very low (Lazonick and Tulum 2011; Mirowski 2011). Still both policy attention and venture capital investment have remained high over the last decades (Pisano 2006). Lazonick and Tulum (2011) argue that this is explained by the propensity of venture capital to rather treat a company, its brand and its intellectual property as assets to be sold on time than to see the company as an investment expected to generate revenue from any sales of an actual product (Lazonick and Tulum 2011).

What consequences does this have for actors in a regional cluster? Livi and Jeannerat (2015) argue that startups are increasingly "born to be sold", that is to be financially appropriated by trans-local actors rather than to develop as mature companies in their cluster. This raises at least two kinds of challenges.

First, analysts have pointed to the problematic political economy of these developments. As Lazonick and Tulum (2011) show, venture capital's ability to capitalise on biotech crucially depends on public investments in early phases of company development. These subsidies are often legitimised through expected future benefits for the region. The critical financialisation literature challenges this rationale and argues that any profits are likely not to be realised in the region (French et al. 2011).

Second, these dynamics also pose a challenge to biotech entrepreneurs and company founders themselves. A part of these entrepreneurs may not be primarily interested in realizing short-term monetary profit, but rather in long-term product development and the pursuit of their own epistemic and development agenda (Fochler 2016a). Accordingly, how to manage relations to venture capital without being forced to exit from the firm before it has concluded its actual project is a key concern of many life science entrepreneurs (Fochler 2016b).

\section{Material and methods}

The data for this paper was collected in a research project that aimed to study the dynamics of knowledge production at the interface of academia and business in the Vienna life science cluster. A central aim of this project was to understand how entrepreneurs and their teams build startup companies both as spaces for doing research and as spaces for doing business, and how the way they institutionally set up their companies relates to their aims in doing so. As core material for this study, I conducted 20 interviews with entrepreneurs, serial entrepreneurs and core research staff. The interviews covered the development of nine different companies in total.

The interviews were based on a biographical approach and focused on researchers' epistemic and career development. They were structured as reflexive conversations on the specificities of the researchers' knowledge production practices and their relation to the specific institutional context in their company. The interviews were conducted in 
2012 and 2013, were between 60 and 120 minutes in length and were audio-recorded and fully transcribed.

In addition to this core material, I conducted five interviews with other central actors in the cluster, such as funding agencies and the cluster management organization. I observed several official cluster events, including the celebration of an official anniversary of the cluster that featured a multi-media presentation of its history. Also, I collected and analysed the official communication of the cluster management organization, most significantly their regular updates on successes in the cluster.

The analytical question about what difference the specific region made in how companies were built and research agendas were pursued was part of the initial project outline, and also considered in the questionnaire. Interestingly, while the direct questions which aimed at this did not produce very rich material, a first open coding of the material revealed that most interviewees used stories of previous experiences in the cluster as a narrative resource to explain their own approach and choices. This paper analyses these accounts.

\section{The genesis of the Vienna biotech cluster}

In international comparison, the Vienna biotechnology cluster may be described as relatively young and as small to medium-sized. In 2015, the statistics of the cluster management institution listed 67 dedicated research-active biotechnology companies, with a total revenue of 99 million euros per year and 870 employees (LISAvienna 2015). Nearly half of all companies were up to 5 years of age, and a total of four out of five had a company history of less than 10 years. Firms are rather small, with more than $60 \%$ counting less than ten employees, and only two companies larger than 50 employees.

Compared to the development of the biotechnology industry in the US, but also in many other European countries, commercial activities in biotechnology in Vienna started relatively late (Trippl and Tödtling 2007). With very few single precursors dating back earlier, the first dedicated biotechnology companies were founded in the late 1990s. In many retrospective accounts, the Institute for Molecular Pathology (IMP) - a private non-profit research institution sponsored by the pharma multinational Böhringer-Ingelheim-and its entrepreneurial director played a key role in many of these early ventures, as did a large basic research site of Novartis, another big pharma player, and a limited number of university scientists working in departments with a longer tradition of the commercial application of biotechnology.

Policy efforts to foster the establishment of this new industry followed this first wave of companies relatively quickly, with a national impulse biotechnology program established in 1999. In the 2000s, the city of Vienna explicitly made the life sciences one of their focal areas in high technology industry development and launched initiatives both to fund high-tech startups and their research as well as to develop the necessary cluster infrastructure. In 2002, the cluster management organization Life Science Austria Vienna Region (LISA VR) was founded as a joint venture of the city's main commercial technology funding agency and the national innovation agency, which soon after developed into the Austria Wirtschaftsservice GmBH (aws) a federal promotional bank offering subsidies and loans to business startups, particularly in the high-tech sector. The 
task of the new LISA agency was both to manage the cluster and foster its development, but also to coordinate regional and national funding efforts and provide a central information point on regional and national funding possibilities.

From its very beginning, but ever more strongly in the growing financial crisis of the late 2000s, the lacking availability of private venture capital was seen as a major challenge for the development of biotechnology in Vienna. Consider how a research funder describes this:

So I'd say there is an enormous difference between the anglo-saxon countries and the rest of Europe, and that is the very limited availability of private capital for high-tech companies. [...] So in the US, there's a pull effect, the money is looking for opportunities, whereas here, the opportunities are looking for money. (research funder, male)

Funding instruments were designed to counter this problem, resulting in a densely knit network of funding and advisory offers from the pre-seed phase of biotechnology companies to their relative maturity. The large majority of funding instruments available in the cluster until today focus on aiding companies in developing their research and business activities under conditions in which private capital is challenging to acquire. In addition to classic development project funding, refundable loans by the promotional bank aws play a key role here. While hardly sufficient and also not intended to fund a company's development fully, these funding instruments were designed to offer company founders an at least partial and temporal independence from the private capital market. Consider how an experienced entrepreneur describes this:

So I'd say over the last decades Vienna has developed a particularly good funding landscape that is also internationally recognized. [...] So its' not that you can live of the public subsidies for years of course. That's not the purpose. But it helps to kick of the initial processes, and then you need to acquire additional private resources to give your company a solid basis. (entrepreneur, male)

The mid-2000s saw the demise of some central companies of the first biotechnology wave in Vienna, but also a strongly increased activity in the founding of new companies, aided by the funding structures established around LISA VR. In my interviews with experienced players in Vienna biotechnology companies, but also with key actors in funding institutions, two factors emerged as a crucial for this increased activity.

On the one hand, larger corporate actors had started to dismantle their Vienna research sites. The final closure of the Novartis research facility due to a global restructuring of the company's research in 2007 affected more than 250 employees in Vienna. On the other hand, starting with a new university law established in 2002 and continuing with the slow institutionalisation of its effects over the next decade, Austrian universities and their research were re-structured along some of the central principles of the new public management. As external funding for their research grew ever more central but also became harder to secure, as a temporalization of research work in 
projects rendered intellectual continuity more difficult, and as new career norms and schemes for junior staff caused principle investigators an increasing struggle to keep experienced researchers and their tacit knowledge in their group, conducting research in biotechnology companies rather than in an academic context became a more interesting option for a significant minority of academics, either as an extension of their academic activities, or as an opportunity for a second career in a new sector. In my interviews with company founders, establishing a company as a sustainable long-term space for their epistemic and commercial activities was a prime motivation for both those with a background in academia and in industry (Fochler 2016a). For academics, a biotechnology company seemed to promise a better, more long-term funding environment for their research as well the opportunity to develop their ideas into tangible applications. Those with a background in industry valued the independence from the vagaries and unpredictability of higher level management decisions, such as the ones that had led to the closure of the Vienna Novartis site. Though from very different backgrounds, academic and industrial company founders agree in their perspective on the startup of a biotechnology company as an effort to establish a space in which they can have comparably high control over the organizational form of their work and pursue their commercially oriented research relatively independently from external influence. Consider how an academic entrepreneur puts this:

I was never into having a company to get rich, but about developing my things further, and [...]. And if a company is the best means to that end, then having company is great. (entrepreneur, male)

All founders interviewed for this study stated a strong preference for building their companies as spaces for both doing interesting intellectual work and for achieving commercial success. None of the interviewees stressed purely financial motivations to any significant extent (Lam 2011). However, particularly those with a background in academia also stressed that the work in their company could not simply be a continuation of their academic curiosity by other means-such a company could not be financially sustainable. As discussed in more detail elsewhere (Fochler 2016a; Fochler and Sigl 2018), the founders studied developed interesting forms of work organization to create sustainable institutional spaces at the interface of academia and business.

\section{Communication and interaction in the Vienna biotech cluster}

Both the company founders and the company researchers interviewed reported a relatively dense network of communication and interaction between firms and between individuals in the cluster. A number of interviewees stressed that the communication in the cluster would focus on mutual learning, rather than on gaining information to secure competitive advantage. The reason given for this was that the companies in the cluster develop very different products, and hence are not in direct competition to each other.

So our relation to the other biotech firms is extremely friction free. We talk to all the other companies, we don't have to hide anything from them. So it's not them who are our enemies, rather the rest of the world are our enemies, right? We have the same problems we need to solve, so we have a very pleasant and friendly basis for communication. (company founder, male) 
Some of these interactions take place at the regular events organised by the cluster management organization, which also serve as access points for newcomers to enter the network. But beyond this, actors in the cluster quickly develop their personal networks along which information is shared.

So there are these [cluster] events. And you catch up a lot of news there. And then of course also privately, I know a lot of people working in smaller companies in the cluster, and also in larger companies. [...] So that's how you also learn a lot of backstage stories, confidentially, so to say. (researcher, female)

But what is the importance of knowing and sharing these news and stories, if it is not to gain competitive advantage over other actors? Consider how a serial entrepreneur describes the importance of sharing experiences in the cluster:

So I think it [cluster dynamics] only starts to be really good as soon as there have been many companies, and many companies have failed; and the founders and the employees have been recycled several times, in a positive sense. Because this develops a culture in which many know how the game is played, how to play it better, what to watch out for, and so on. That takes the time of an entire generation. But we're getting there. (serial entrepreneur, male)

\section{Narrative learning in the cluster}

Stories about the success and failure of earlier firms played an important role in informal talk in the cluster. In the official presentation and press releases of the cluster management organization of course, successes abounded, and failures were hardly ever mentioned. Successful funding rounds, new milestones in clinical trials as well as the acquisition of a product or of an entire company by international actors were reported and celebrated, while the liquidation of failed companies was not. This is hardly surprising of course, given that the task of a cluster management organisation is to represent and promote the area as a successful knowledge hub.

In informal talk at events or in my interviews, stories about past successes and failures had an important function. They were referred to and told to point to typical problems that may arise in the development of biotech companies and to discuss how these pitfalls may be avoided. In my biographical interviews with company founders, they were often invoked to account and legitimate the choices the funders had made in building their company. Serial entrepreneurs referred to their own past experiences, but also novice entrepreneurs would refer to a set of well-known and well re-hearsed stories. Some of these stories were about obvious failures, but interestingly, some were also about companies whose trajectory officially had been labelled a success, but which were discussed as a failure to be avoided behind the scenes.

An example regularly referred to was a technology company, which had rapidly developed a technology invented in a university context to a leading commercial asset. With substantial license agreements with a big pharmaceutical company and high capital investments by several international venture capital funds, the company was 
regularly featured as a success in official channels. The story told in informal contexts however does not highlight this aspect. It tells how the increasing influence of external investors had led to first the founders being required to exit from active management, and how then management had decided to re-locate the company's research operation to a more prestigious location than Vienna, also resulting in the exchange of nearly all research personnel.

This example shows that different implicit definitions of success and failure are at play in official stories and in informal tales about the same company. As a commercialisation effort, the company clearly had been an enormous success, attracting high amounts of capital, and probably also rendering substantial profit to the initial founders upon exit. But at the same time, for many founders I interviewed, this was also an example of what they would not like to happen to their company. For many of them, building a sustainable company which would allow them to work on their research and commercialisation projects was more important, and the moral of the story was to avoid precisely such a trajectory.

We don't want such a risky business model. So in our company, we don't develop a therapeutic product for which you'll never know whether that works in the end. But we sell cell lines that can be used as model system. So in this biotech gold rush, we don't dig. We sell the shovels. So we won't be as rich as those hitting a mine, but we will be able to fund our own research from our revenues. And we already do. [...] Also building on the experiences of company A, I guess you heard about that? [I: Yes.] That as soon as venture capital has the majority of shares, they move everything to [country]. That's not going to happen to us. (entrepreneur, male)

He continued to explain that he would use the revenues from their technology projects to fund riskier research and development projects, and how he would enjoy the freedom of being able to do so without acquiring external funds. Interestingly, he described this strategy as being part of the culture of his biotechnology department, as the prior head of this department had founded some of the very first biotechnology companies in Austria and was said to have used the profits in precisely this way.

In this story as in others, the involvement of venture capital in a company was seen as a threat. Besides the issue of control over company decisions, founders described three other potentially problematic impacts on a company's operations and long term prospects.

The first is connected to the different temporal regimes in which venture capital funds and biotechnology companies operate. The development of a new drug candidate to the point at which it finally may be sold to a pharmaceutical company for the last stage of clinical trials may take 10 years or more after the initial founding of the company. $\mathrm{VC}$ funds are operating on shorter time horizons, after which they expect a return on their investment. As companies following a classical biotechnology business model, however, do not generate any revenues before this actual sale, venture capital funds are seen as likely to push a premature sale of either the entire company or parts of their intellectual assets. This in turn was seen 
as likely to again result in the founders losing control over their company, but also as endangering the company's entire development trajectory, as it for example may be acquired by a competitor interested in ending its operations.

So of course these VC [venture capital] funds are under an enormous pressure themselves to provide interest for their investors. And that is a very bad fit with what a biotech company needs. Because that's about long-term stuff. Product development of therapeutics takes at least ten years. And VC funds have a turnaround of say five to seven years. Which means that at some point they start applying enormous pressure to sell the company, even though it might not be mature enough. And that leads to some very irrational actions. [...] And that's a situation I don't want to be in again, because it has enormous costs on the human side. Like having to fire people you don't want to fire because a fund needs to exit. (serial entrepreneur, male)

Second, related to this first point, venture capital was also seen as likely to push companies into a too rapid development pathway, in order to prep them for a sale. Company founders described the methodological and diligent development of their potential product and its precise documentation as of key importance for being able to offer it to a pharmaceutical company at the end of the development trajectory. Focusing a company's efforts to achieve a potentially sensational interim result was seen as endangering this diligence, and potentially detrimental in a long term perspective.

The danger is being pushed into development strategies that are too quick, for example, to reach a data point that might be presented as a highlight in a sale. But then quality falls by the wayside. And in the long term, that gets back at you. It's like in academia where people are being pushed to publish as much as possible in top journals, regardless of the content, right? So we would say: we're in phase 2 clinical development. [...] But there's a lot of homework not done along the way. And if Big Pharma looks at that in due diligence, then it's going to come back at you.

(entrepreneur, male)

Third, particularly serial entrepreneurs described the representatives of venture capital as highly conservative in their influence on epistemic decisions within the company.

So, basically, venture capital was in a permanent state of anxiety if not everything was done on a run-of-the-mill basis. (serial entrepreneur, male)

Both founders from an industrial and academic background stressed that a biotechnology company allowed them to purse potentially more risky and innovative ideas than their previous institutional context. Those coming from academia would argue that the typical peer review process in academic research funding is biased against attempts that are seen as too risky. Researchers with an industrial background made the same arguments about higher level management decisions. 
Besides the dangers of involving venture capital, problems of growth were a second trope in the informal stories circulating in the cluster. In telling them, founders would point to the danger of "growing too quickly" and often legitimate their decision to keep their company small, even if this means not taking up specific opportunities. In the stories told, particularly about the demise of one specific company, too rapid growth led to a fragmentation of internal communication and in consequence to conflicting camps fighting each other within the company. Some interviewees would also use the same story to stress that growth beyond a certain point would require more formal organizational structures which would destroy the organizational and epistemic flexibility of a typical high-tech startup. This latter argument was particularly used by founders with an industrial background, who partly had left larger industrial corporations to escape precisely such structures.

So I've now seen two risk capital financed companies really up a close. So I know the advantage of having a lot of money, but I also know the downsides. All has its price, and at the moment I really want a bit more control over my company. With [company name] we were at 100 million in capital, with [company name] I think we're at 40 million. But that money really is used very inefficiently. [...] That's one of my main motivations to do it differently. (serial entrepreneur, male)

In addition to these two main story tropes, founders did refer to a range of smaller stories and examples to illustrate mistakes that should be avoided in the development of a biotechnology company, such as an imbalanced definition of milestones triggering further funding, or a too wide and unfocused research portfolio lacking a clear commercial trajectory. These examples were also cited as important know-how to be passed on to novice entrepreneurs in business plan competition consultations or other similar situations.

This section has mainly explored negative stories about prior commercialisation efforts and aimed to show how founders refer to them as examples to be avoided in the development of their own companies. There also were success stories, mainly of companies which in the perspective of the founders interviewed had successfully developed strategies to avoid the problems sketched in this section. These stories will be reported in the next section, which will deal with founders' strategies of avoiding the pitfalls sketched in the stories reported in this section.

\section{Experimenting with business models and research strategies}

Founders used the stories described in the preceding section to illustrate and explain how the strategic choices they made in developing their company built on their own prior experiences and those made in the cluster. For all, constructing a reflexive business plan of the future epistemic, organizational and commercial development of their company was crucial. In this, shaping the company to fit their respective vision of a rewarding environment for both everyday work, but also for the long-term realisation of their epistemic and commercial aims, was central. Maintaining control over their own company and avoiding a too strong influence of external capital was an important issue for most. Entrepreneurs described three different basic strategies to do so. In all of these strategies, the public funding provided was seen as crucial particularly in early 
phases, but as by no means sufficient to support the long-term operation of the company.

The first and most common strategy was to orient at least a part of the company's activities so that they are able to generate revenues by selling a product relatively quickly, within the first years of the company's operation. Consider how the founding chief scientific officer of a company characterises this:

So most biotech companies are actually just burning money. So if you look around, even the most important companies on the Austrian biotech market, they've burned an enormous amount of money and have very little in their pipeline. [...] So most never get to the point where they actually sell something. So but we are working towards achieving something that generates at least a small profit in the short term. And we're deliberately working towards this with a small budget, so we don't have to involve venture capital. Which significantly increases our freedom to decide.

(researcher, male)

As a swift commercialisation of actual biotechnology drugs is very difficult if not even impossible, for a number of companies this meant orienting major parts of their research operations to developing a research technology product to be sold to other companies and academic research. Having such a product in turn could generate financial resources to do other kinds of research and development work.

Because we have this product on the market, that gives us the freedom to look into things that other companies cannot look into because they lack the capital for it. And the cool thing here is that both our bosses are dyed-in-the-wool scientists. So when they're interested in something, then they will spend that money. (researcher, female)

The particular company this researcher worked at was often referred to as an example that having a product on the market early in the company's trajectory is also possible in drug development. This company had succeeded in licensing one of its first products as a medical device for over the counter sale in pharmacies, thus avoiding most of the intense licensing efforts for classical drugs. The company could then use the revenues to decrease its dependence on external investors and public funding, which was seen as an inspiration by other founders, but also was used as an example for a creative sustainable business plan by cluster management officials.

A second strategy for avoiding influence of venture capital was to develop a network of individual private investors, combined with public funding. Particularly one company in the cluster whose CEO had made prior negative experiences with venture capital was often cited as a reference here. This strategy was seen as allowing the company to be more open in its development pathway, as it both avoided the influence of venture capital and the necessity to focus on technology development to generate revenues. However, it was also seen as carrying considerable risks. First, convincing many private investors was seen as requiring considerable effort. Second, private backers were seen as of potentially limited reliability, particularly during re-financing rounds which would require them to provide additional funds. 
So, yes, [our company] has no venture capital. And that has not only happened because I would never again in my life work with venture capital, but also because we wouldn't get any. [...] So this developed from one private investor to the next, and now we have more than forty and a license deal with [a big pharma company]. And it works alright. But it's not easy in a business in which things take forever and in which the likeliness that things will work is in the lower single digit percent range. [...] It's really not easy to explain setbacks to people who have invested their hard earned money. But it's still much better than the alternative. (serial entrepreneur, male)

The third strategy for avoiding venture capital influence was seen as entering a strategic development partnership with a large pharmaceutical company very early in the development process, rather than developing the product on one's own and offering it to different companies at a later stage. The advantage of such a strategy was seen in being able to orient the work process towards the long-term necessities of drug development rather than having to consider the importance of presenting development highlights for the next financing round. While again one company in the cluster was seen as a successful example of this strategy, founders were aware that pharmaceutical companies offer such cooperation agreements to early stage biotechnology companies only in very rare cases.

So the mindset of big pharma and that of a biotech company on data quality and the life cycle of the product, that's of course quite a bit closer than that of a biotech company and venture capital. (entrepreneur, male)

Choosing a sector which was not too "hot" and competitive was another strategy reported by founders aiming to maintain control over their company in the longer term. Hot and competitive topics would require companies to grow and increase their research capacities fast to be able to potentially outrun their competitors. This in turn would require both high (venture) capital investments and risk the problems of growth associated with the stories analysed in the preceding section.

\section{Discussion}

How do specific regional styles of building companies and industry/academia/government relations develop? This paper has focused on company founders and their staff as institutional entrepreneurs that play a crucial role in shaping these relations. It argues that narrative learning in the specific regional community of practice plays a crucial role in this. The empirical parts of this paper have shown how and where experiences are exchanged in communication within this community of practice. Further, they have analysed how entrepreneurs draw on stories of past experiences in the cluster to make sense of and legitimate their own decisions in building their companies. These stories influenced how company founders set up their companies, on multiple levels, concerning the social organization of the company and its potential for growth, the research focus of the company and the company's financing model.

These decisions can be expected to have significant consequences on how triple helix relations develop in the cluster. Narrative learning in the community of practice of 
company founders is an important dynamic of regional cluster formation, because it links the level of individual agency and decision making to collective dynamics and institutional structures. More research is needed to address the relation of this form of learning to other crucial processes of regional learning (e.g. cognitive learning) and cluster formation (e.g. regional innovation system dynamics).

A central topic negotiated in making sense of stories in the cluster was the meaning of success and failure. In particular, founders' understanding deviated significantly from a purely profit-based understanding of success and failure that is often characteristic of official discourses within a cluster. Consistent with other literature (Lam 2011), the founders interviewed placed higher emphasis on building sustainable companies and the corresponding intellectual and social rewards than on direct financial rewards. More research is needed to understand in how far these dynamics are particular to the Vienna biotech cluster studied in this paper.

The dynamics of financialisation (Birch 2017b; French et al. 2011) and their consequences for their institutional projects were central to the founders' consideration of how to set up their companies. In particular, the perceived incompatibility of the interests and temporalities of venture capital with the needs of a biotechnology startup were seen as a problem. This shows that company founders as institutional entrepreneurs (Battilana et al. 2009) are reflexively aware of the problematic dynamics of financialisation in life science innovation, and try to consider these problems in their own actions. This invites future research on the role of reflexivity in the practices of institutional entrepreneurs.

\section{Policy recommendations}

The findings of this study show that cluster management organizations provide important infrastructures for narrative learning within the cluster, and hence make an important contribution to the development of sustainable business models. This "softer" side of cluster management practices needs to be valued accordingly.

The experiences of the entrepreneurs reported in this paper corroborate the importance of strong public regional innovation financing (Etzkowitz and Etzkowitz 2017), both to compensate a possible lack of private venture capital, but also to allow regional policy more influence on how the funded activities will benefit the region.

In relation to regional benefits, how to deal with financialisation (Birch 2017b; French et al. 2011) is a key issue to consider for policy and cluster management. In particular, whether companies are expected to develop as sustainable institutions that keep and develop human resources and intellectual property within a region, or whether they are seen as assets to be capitalised on by mostly non-regional venture capital is a fundamental question of the regional political economy.

\section{Additional file}

Additional file 1: Translation of the abstract into Arabic. (PDF $40 \mathrm{~kb}$ )

\section{Abbreviations}

aws: Austria Wirtschaftsservice GmBH; IMP: Institute for Molecular Pathology; LISA VR: Life Science Austria Vienna Region; VC: Venture Capital 


\section{Funding}

This work was supported by the Austrian Academy of Sciences through an APART scholarship.

\section{Availability of data and materials}

The datasets generated and/or analysed during the current study are not publicly available due to reasons of confidentiality but are available from the corresponding author on reasonable request.

\section{Author's contributions}

$M F$ is the sole responsible author of this paper. The author read and approved the final manuscript.

\section{Authors' information}

Maximilian Fochler is an associate professor at the Department of Science and Technology Studies of the University of Vienna, Austria. His main current research interests are forms of knowledge production at the interface of science and other societal domains (such as the economy), as well as the impact of new forms of governing science on academic knowledge production. He has also published on the relations between technosciences and their publics as well as on publics' engagement with science.

\section{Competing interests}

The author declares that he has no competing interests.

\section{Publisher's Note}

Springer Nature remains neutral with regard to jurisdictional claims in published maps and institutional affiliations.

Received: 12 September 2018 Accepted: 11 October 2018

Published online: 26 October 2018

\section{References}

Autio E, Kenney M, Mustar P, Siegel D, Wright M (2014) Entrepreneurial innovation: the importance of context. Res Policy 43: 1097-1108. https://doi.org/10.1016/.respol.2014.01.015

Avnimelech G, Teubal M (2006) Creating venture capital industries that co-evolve with high tech: insights from an extended industry life cycle perspective of the Israeli experience. Res Policy 35:1477-1498. https://doi.org/10.1016/j.respol.2006.09.017

Bathelt H, Malmberg A, Maskell P (2004) Clusters and knowledge: local buzz, global pipelines and the process of knowledge creation. Prog Hum Geogr 28:31-56. https://doi.org/10.1191/0309132504ph469oa

Battilana J, Leca B, Boxenbaum E (2009) How actors change institutions: towards a theory of institutional entrepreneurship. Acad Manag Ann 3:65-107. https://doi.org/10.5465/19416520903053598

Birch K (2017a) Innovation, regional development and the life sciences: beyond clusters. Routledge, New York

Birch K (2017b) Rethinking value in the bio-economy: finance, assetization, and the management of value. Sci Technol Hum Values 42:460-490. https://doi.org/10.1177/0162243916661633

Cooke P (2001) Regional innovation systems, clusters, and the knowledge economy. Ind Corp Chang 10:945-974. https:/doi. org/10.1093/icc/10.4.945

Crevoisier O (2004) The innovative milieus approach: toward a territorialized understanding of the economy? Econ Geogr 80: 367-379. https://doi.org/10.1111/j.1944-8287.2004.tb00243.x

Czarniawska-Joerges B (1998) A narrative approach to organization studies. Qualitative research methods series/qualitative research methods series, vol 43 . Sage, Thousand Oaks

Etzkowitz A, Etzkowitz H (2017) Counter-cyclical public venture capital: debt-funding as an anti-austerity innovation strategy. Soc Sci Inf 56:477-495. https://doi.org/10.1177/0539018417719795

Etzkowitz H (2018) The triple helix: university-industry-government innovation and entrepreneurship, 2nd edn. Routledge, London

Etzkowitz H, Ranga M (2015) Triple Helix systems: an analytical framework for innovation policy and practice in the knowledge society. In: Entrepreneurship and knowledge exchange. Routledge, pp 117-158

Feldman M, Francis J, Bercovitz J (2005) Creating a cluster while building a firm: entrepreneurs and the formation of industrial clusters. Reg Stud 39:129-141. https://doi.org/10.1080/0034340052000320888

Fochler M (2016a) Beyond and between academia and business: how Austrian biotechnology researchers describe high-tech startup companies as spaces of knowledge production. Soc Stud Sci 46:259-281. https://doi.org/10.1177/ 0306312716629831

Fochler M (2016b) Variants of epistemic capitalism: knowledge production and the accumulation of worth in commercial biotechnology and the academic life sciences. Sci Technol Hum Values 41:922-948. https:/doi.org/10.1177/0162243916652224

Fochler M, Sigl L (2018) Anticipatory uncertainty: how academic and industry researchers in the life sciences experience and manage the uncertainties of the research process differently. Sci Cult 27:349-374. https://doi.org/ $10.1080 / 09505431.2018 .1485640$

French S, Leyshon A, Wainwright T (2011) Financializing space, spacing financialization. Prog Hum Geogr 35:798-819. https:// doi.org/10.1177/0309132510396749

Haeussler C, Colyvas JA (2011) Breaking the ivory tower: academic entrepreneurship in the life sciences in UK and Germany. Res Policy 40:41-54

Håkanson L (2005) Epistemic communities and cluster dynamics: on the role of knowledge in industrial districts. Ind Innov 12:433-463. https://doi.org/10.1080/13662710500362047

Hassink R, Klaerding C (2012) The end of the learning region as we knew it; towards learning in space. Reg Stud 46:10551066. https://doi.org/10.1080/00343404.2012.705823

Healy A, Morgan K (2012) Spaces of innovation: learning, proximity and the ecological turn regional studies, pp 1-13. https:// doi.org/10.1080/00343404.2012.672725 
Huggins R, Johnston A, Steffenson R (2008) Universities, knowledge networks and regional policy. Camb J Reg Econ Soc 1: 321-340. https://doi.org/10.1093/cjres/rsn013

Lagendijk A (2006) Learning from conceptual flow in regional studies: framing present debates, unbracketing past debates. Reg Stud 40:385-399. https://doi.org/10.1080/00343400600725202

Lam A (2011) What motivates academic scientists to engage in research commercialization: "gold", "ribbon" or "puzzle"? Res Policy 40:1354-1368. https://doi.org/10.1016/J.Respol.2011.09.002

Lazonick W, Tulum Ö (2011) US biopharmaceutical finance and the sustainability of the biotech business model. Res Policy 40:1170-1187

LISAvienna (2015) Vienna life science report 2015/2016. LISAvienna, Vienna

Livi C, Jeannerat H (2015) Born to be sold: start-ups as products and new territorial life cycles of industrialization. Eur Plan Stud 23:1953-1974. https://doi.org/10.1080/09654313.2014.960180

Malmberg A, Power D (2005) (How) do (firms in) clusters create knowledge? Ind Innov 12:409-431. https://doi.org/10.1080/ 13662710500381583

Massey D (2005) For space. Sage, London

Mirowski P (2011) Science-mart: privatizing American science. Harvard University Press, Cambridge

Molina-Morales FX, Martínez-Cháfer L (2014) Cluster firms: you'll never walk alone Reg Stud. 1-17 doi:https://doi.org/10.1080/ 00343404.2014 .952719

Moodysson J (2008) Principles and Practices of Knowledge Creation: On the Organization of "Buzz" and "Pipelines" in Life Science Communities Economic Geography, vol 84, pp 449-469. https://doi.org/10.1111/j.1944-8287.2008.00004.x

Pisano GP (2006) Science business: the promise, the reality, and the future of biotech. In: Harvard Business School Press. Mass, Boston

Porter K, Whittington KB, Powell WW (2005) The institutional embeddedness of high-tech regions : relational foundations of the Boston biotechnology community. In: Breschi S, Malerba F (eds) Clusters, networks, and innovation. Oxford University Press, Oxford; New York, pp 261-296

Rutten R, Boekema F (2012) From learning region to learning in a socio-spatial context. Reg Stud 46:981-992. https://doi.org/ $10.1080 / 00343404.2012 .712679$

Trippl M, Grillitsch M, Isaksen A, Sinozic T (2015) Perspectives on cluster evolution: critical review and future research issues. Eur Plan Stud 23:2028-2044. https://doi.org/10.1080/09654313.2014.999450

Trippl M, Tödtling F (2007) Developing biotechnology clusters in non-high technology regions-the case of Austria. Ind Innov 14:47-67. https://doi.org/10.1080/13662710601130590

Wenger E (1998) Communities of practice: learning, meaning, and identity. Learning in doing. Cambridge University Press, Cambridge

\section{Submit your manuscript to a SpringerOpen ${ }^{\circ}$ journal and benefit from}

- Convenient online submission

- Rigorous peer review

- Open access: articles freely available online

High visibility within the field

- Retaining the copyright to your article

Submit your next manuscript at $\boldsymbol{\nabla}$ springeropen.com 